\title{
ASSESSMENT OF CHANGES IN POPULATION AGEING IN REGIONS OF THE V4 COUNTRIES WITH APPLICATION OF MULTIDIMENSIONAL SCALING
}

The study investigates the variation in population ageing in four Visegrad countries (V4) and across their NUTS2 regions in 2016 compared to 2005. Population ageing was assessed using the median age, old-age rate, double ageing index, ageing index, and old-age dependency ratio. The authors took into account causes that explain changes occurring at the bottom and at the top of the population pyramid. By applying multidimensional scaling combined with the composite indicator and the Theil decomposition, the study identified differences in the level of population ageing in a two-dimensional space and the dynamics of these changes. Such an approach, with the visualization of the results, enriches this interpretation. In the reference period the process of population ageing in the V4 countries and their regions accelerated considerably. The disproportion between regions has increased in Slovakia, slightly increased in Poland, and decreased in the Czech Republic and Hungary.

Keywords: multidimensional scaling, Theil decomposition, composite indicators, ageing, $\mathrm{R}$ program

JEL Classifications: J11, J14, C38, C43, C88

DOI: $10.15611 /$ aoe.2020.1.04

\section{INTRODUCTION AND LITERATURE OVERVIEW}

The problems of elderly people and population ageing have been the subject of demographic research for a number of years. In the mid-20 $0^{\text {th }}$ century, Alfred Sauvy (Sauvy 1957), emphasizing the fact that the population of Europe had been growing old for over 100 years, warned against underestimating the impact of this process on the lives of individual people and entire societies (Rosset 1967). At present the demographic literature on population ageing is very broad and explores various aspects of the problem. First of all, population ageing is analysed in relation to economic issues, living

\footnotetext{
* Poznań University of Economics and Business, ORCID:0000-0002-0072-9681.

** Poznań University of Economics and Business, ORCID:0000-0001-5570-9576.

${ }^{* * *}$ Wrocław University of Economics and Business, ORCID: 0000-0003-0922-2323.
} 
conditions, the welfare state, pension security and implications for the labour market (Lee and Mason 2010; Lee and Edwards 2002; Metz 2000; Bongaarts 2004; Börsch-Supan 2003). In addition to studies of the economic and social effects of population ageing, research focuses on investigating sources of demographic changes, variation in the dynamics of basic demographic processes and their impact on the current and future demographic situation (Preston et al. 1989; Lutz et al. 2006; Goldstein et al. 2009). Another important area of research is associated with social care, health care and disability (Miller 2001). In the second decade of the 21st century, population ageing in European countries has become so advanced that it is now regarded as a key demographic problem and is addressed in discussions involving scientific and social institutions as well as agencies of local governments (Murphy 2017; World Population Ageing 2015; The 2015 Ageing Report 2015; Bussolo et al. 2015; Beard et al. 2012). According to the UN, in $201725 \%$ of Europeans were at least 60 years old. This figure is predicted to increase to $35 \%$ by 2050 (World Population Prospects... 2017). The projection indicates the seriousness of the problem and the urgent need for more in-depth research on this phenomenon.

The purpose of the study is to evaluate changes in population ageing in regions of the Visegrad Group (V4) countries between 2005 and 2016 taking into account the degree of advancement of population ageing, the character of these changes and their territorial differentiation ${ }^{1}$. Statistical data used in the study come from the REGIO database maintained by Eurostat and are based on the NUTS classification of territorial units. The data describe the scope of population ageing in 35 NUTS2 regions of the V4 countries ( 8 Czech regions, 7 Hungarian regions, 16 Polish provinces, and 4 Slovak regions) in 2005 and in 2016. For comparative purposes, the dataset has been extended to include statistics for V4 countries (the Czech Republic, Poland, Slovakia, Hungary) and the European Union (EU-28) as a whole. The comparative analysis of the degree of population ageing and its spatial variation across the regions of interest is based on multidimensional scaling combined with linear ordering and the use of the Theil decomposition.

The analysis of changes observed in the reference period is limited to identifying direct causes, which are linked to trends in fertility and mortality rate and their consequences for specific demographic structures. The

\footnotetext{
${ }^{1}$ The article is a significantly changed and expanded version of the text published in Polish (Dehnel et al. 2018).
} 
analysis does not address indirect causes, such as the effect of migration. The present study of population ageing across regions of the V4 countries is mainly motivated by the exceptionally dynamic changes in the demographic processes observed in these countries during the period of political and economic transformation, and the fact that there is relatively little research on the subject. One of the few studies that do exist is the work by Káčerová and Ondačková (2015). Other studies devoted to similar topics do not cover the V4 region, perhaps because of its distinctive character (Murphy 2017). The spatial variation of population ageing has been investigated in many studies as it provides the basis for comparative analysis, which helps to observe differences and identify causes. In his study, Murphy analysed 11 European countries with the exclusion of countries in Central-Eastern Europe. Changes in demographic structures across all European countries were examined in studies by Káčerováet al. (2014).

\section{RESEARCH METHODOLOGY}

The variables used to describe objects of interest can be classified as three kinds of preferential variables: stimulants, destimulants and nominants. Definitions of stimulants and destimulants are available e.g. in Walesiak (2016). When a complex phenomenon (in this case, it is the degree of advancement of population aging), represented on the $y$-axis, is decreasing, it can be represented graphically as in Figure 1.

As the data refer to two different periods $t$ and $q(t>q)$, it was necessary to transform nominants into stimulants (this is required by the structure of the anti-pattern object) and construct a common pattern and an anti-pattern object based on a data matrix $\mathbf{X}^{\prime}=\left[x_{i j}^{\prime}\right]\left(x_{i j}^{\prime}-\right.$ observation of $j$-th variable for $i$-th object $-i=1,2, \ldots, n-$ object number, $j=1, \cdots, m-$ variable number), which includes data from period $t$ and $q$ (the pattern object (upper pole) represents the most favourable values of preferential variables, an anti-pattern object (lower pole) represents their least favourable values. For a given set of objects, the pattern object represents an object characterised by the lowest degree of advancement of population ageing, while the anti-pattern object, an object representing the highest degree of advancement. Hence, data matrix $\mathbf{X}=\left[x_{i j}\right]$ has dimensions $(2 n+2) \times m$. Next, the authors normalised variable values for the joint data matrix $\mathbf{X}=\left[x_{i j}\right]$ to receive normalized data matrix $\mathbf{Z}=\left[z_{i j}\right]$ for $i, k=1, \cdots, 2 n+2$ 
and $j=1, \cdots, m\left(z_{i j}-\right.$ the normalized value of the $j$-th variable for the $i$-th object. Normalization methods are available in the data, And the normalization function from the clusterSim package (Walesiak and Dudek 2018a). A similar procedure for data normalization is available in the scale function from the base package. In this function, it is possible to define the parameters location and scale.

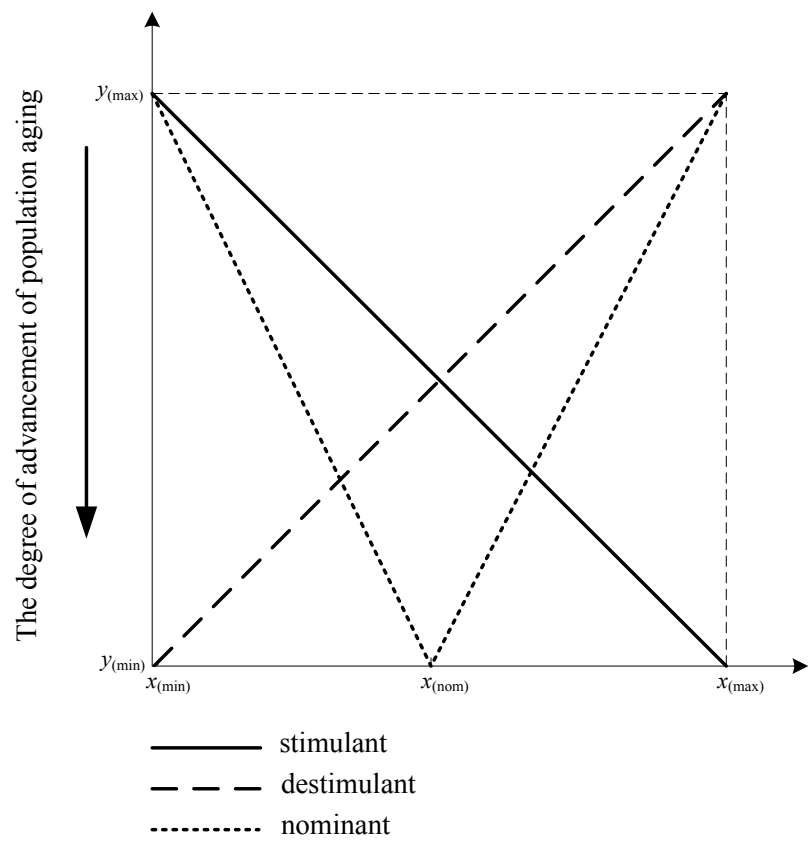

Fig. 1. Graphic representation of preferential variables $\left(x_{(\text {пот) }}-\right.$ nominal value of a variable).

Source: own presentation.

Next, a distance measure was selected (Manhattan, Euclidean, squared Euclidean, Chebyshev, Generalized Distance Measure GDM1 - see Jajuga et al. 2003; Everitt et al. 2011, pp. 49-50) to calculate a distance matrix in an $m$-dimensional space $\boldsymbol{\delta}=\delta_{i k}(\mathbf{Z})$ for $i, k=1, \cdots, 2 n+2$.

To obtain a ranking of objects of interest based on normalized data matrix $\mathbf{Z}=\left[z_{i j}\right]$ in terms of the degree of advancement of population ageing, the authors used a two-step procedure proposed by Walesiak (2016), which facilitates the visual representation of linear ordering results. 
In the first step, after applying multidimensional scaling (MDS), the objects are represented in a two-dimensional space. Multidimensional scaling maps distances in an $m$-dimensional space $\delta_{i k}(\mathbf{Z})$ into corresponding distances $d_{i k}(\mathbf{V})$ in an $s$-dimensional space $(s<m)$ by a representation function $f: \delta_{i k}(\mathbf{Z}) \rightarrow d_{i k}(\mathbf{V})$ (for all pairs $(i, k)$ ). The distances $d_{i k}(\mathbf{V})$ are always unknown. That is, MDS must find a configuration $\mathbf{V}=\left[v_{i j}\right]_{(2 n+2) \times s}$ of predetermined dimensions $s$ for which the distances are computed. In order to enable graphical representation of linear ordering results, $s$ is set to 2 . The iterative SMACOF algorithm is described in Borg and Groenen (2005, pp. 204-205). The algorithm is used to select an optimal procedure for multidimensional scaling. The procedure, implemented in the mdsOpt R package (Walesiak and Dudek 2018b) is an application of the smacofSym function from the smacof package (Mair et al. 2017).

In the second step, objects are ordered linearly using an aggregated measure (composite indicator) $d_{i}$ based on the Euclidean distance from the pattern object (Hellwig 1981, p. 62):

$$
d_{i}=1-p_{i}=1-\sqrt{\sum_{j=1}^{2}\left(v_{i j}-v_{+j}\right)^{2}} / \sqrt{\sum_{j=1}^{2}\left(v_{+j}-v_{-j}\right)^{2}},
$$

where: $p_{i}-$ degree of advancement of population ageing, $v_{i j}-j$-th coordinate for the $i$-th object in the 2-dimensional MDS space, $v_{+j}\left(v_{-j}\right)$-j-th coordinate for the pattern object (anti-pattern) in the 2-dimensional MDS space.

Values of aggregated measure $d_{i}$ are included in the interval [0;1]. The higher the value of $d_{i}$ (the lower $p_{i}$ ), the younger the population of the target object (region, country). Target objects are ranked according to the descending values of the aggregated measure (1).

In the end, as a result of applying the optimal multidimensional scaling procedure, a data matrix $\left[v_{i j}\right]_{(2 n+2) \times 2}$ is obtained, which serves as the basis for graphical presentation and interpretation of results in a 2-dimensional space (output of multidimensional scaling) and unidimensional space (output of linear ordering based on aggregated measure $d_{i}$ ). 
In a diagram representing a two-dimensional space (the output of multidimensional scaling), the points representing the pattern object and antipattern object are connected by a straight line in order to obtain the so-called axis of the set. The pattern object is used to determine isoquants of development (curves of similar development). The objects found between the isoquants represent a similar level of development. The objects correspondding to different points located on the same isoquant can have the same level of development (owing to a different configuration of variable values). This kind of visualization enhances the interpretation of the output of linear ordering.

To obtain a general assessment of the degree of advancement of population ageing and its spatial variation in the regions of the V4 countries between $2005\left(d_{i q}\right)$ and $2016\left(d_{i t}\right)$, the following measure was used:

$$
W_{t q}^{2}=\frac{1}{n} \sum_{i=1}^{n}\left(d_{i t}-d_{i q}\right)^{2}
$$

The measure $W_{t q}^{2}$ equals 0 when aggregated measures $d_{i t}$ and $d_{i q}$ are the same. The square root of formula (2) represents the average magnitude of deviations of aggregated measures $d_{i t}$ and $d_{i q}$. The quantity expressed by formula (2) can be decomposed into three components:

$$
W_{t q}^{2}=W_{1}^{2}+W_{2}^{2}+W_{3}^{2} .
$$

The decomposition of formula (2) into three components was taken from Theil's decomposition of the MSE (Theil 1961) - see Polasek (2013, p. 6). Component measures $W_{1}^{2}, W_{2}^{2}, W_{3}^{2}$ given by formulas (4) - (6) represent the 'magnitude' and 'character' of differences in aggregated measures $d_{i t}$ and $d_{i q}$ resulting from:

a) the difference between mean values:

$$
W_{1}^{2}=\left(\bar{d}_{\bullet t}-\bar{d}_{\bullet q}\right)^{2},
$$

b) the difference in the dispersion:

$$
W_{2}^{2}=\left(S_{t}-S_{q}\right)^{2},
$$


c) the inconsistency in the direction of changes:

$$
W_{3}^{2}=2 S_{t} S_{q}(1-r) \text {, }
$$

where: $\bar{d}_{\bullet}, S_{t}\left(\bar{d}_{\bullet q}, S_{q}\right)$ denote, respectively, the arithmetic mean and standard deviation of $t$-th ( $q$-th) aggregated measures $d_{i t}$ and $d_{i q}, r$ - Pearson's coefficient of linear correlation between $\underline{d}_{\bullet t}=\left(d_{1 t}, \cdots, d_{n t}\right)$ and $\underline{d}_{\bullet q}=\left(d_{1 q}, \cdots, d_{n q}\right)$.

\section{EMPIRICAL RESULTS}

The empirical study used statistical data that reflect the degree of advancement of population ageing in 35 regions of the V4 countries in 2005 and in 2016. Measures of population ageing were selected mainly based on results of existing studies. A set of five metric variables was proposed, which ensure the highest degree of differentiation between the regions of interest:

$\mathrm{x} 1$ - median age of population (in years),

$\mathrm{x} 2$ - old-age rate (percentage of the population aged 60 and over in the total population),

$\mathrm{x} 3$ - double ageing index (percentage of the population aged 80 and over in the population aged 60 and over),

$\mathrm{x} 4$ - ageing index (the number of people aged 60 and over per 100 youths under age 15),

x 5 - old-age dependency ratio (the number of persons aged 65 and over per 100 persons aged 15-64).

The proposed set of variables accounts for changes in population ageing both at the base and at the top of the population pyramid. Given the fact that increasing values of variables $\mathrm{x} 1-\mathrm{x} 5$ correspond to the increasing degree of advancement of population ageing (see Figure1), the variables should be classified as destimulants. The target measures are examples of traditional measures of population aging, which are based on chronological (calendar) age. The literature provides alternative measures of population ageing (see: Sanderson and Scherbov 2010) based on potential (prospective) age (while calendar age represents the number of years that a person has lived, potential age refers to the number of years that a person has left to live).

The set of 80 objects of study (data for 40 objects for 2005 and 2016) was extended to include the pattern object with coordinates $\mathrm{P}=(32.9,14.53$, $12.51,72.99,15.3)$ and the anti-pattern object with coordinates $\mathrm{AP}=(43.8$, 
$27.32,21.34,198.92,29.3)$. The resulting data matrix contains 82 objects described by five variables.

To select the optimal scaling procedure, the authors considered ten normalization methods ( $\mathrm{n} 1, \mathrm{n} 2, \mathrm{n} 3, \mathrm{n} 5, \mathrm{n} 5 \mathrm{a}, \mathrm{n} 8, \mathrm{n}$ 9, n9a, n11, n12a), five distance measures (Manhattan, Euclidean, squared Euclidean, Chebyshev, Generalized Distance Measure GDM1) and 4 multidimensional scaling models (ratio, interval, polynomial of degree 2 and 3 - see: Borg and Groenen 2005, p. 202), obtaining 200 procedures of multidimensional scaling. By applying the mdsOpt $\mathrm{R}$ package, the authors selected the optimal multidimensional scaling procedure, which involves positional standardization (normalization method $\mathrm{n} 2$ ), the interval MDS model and the Generalized Distance Measure for metric data (GDM1).

By applying the optimal multidimensional scaling procedure, the study managed to represent inter-relationships existing between the target regions in terms of population ageing, described by five variables in a twodimensional space.

Figure 2 is a graphic representation of the multidimensional scaling of 82 objects in terms of the degree of advancement of population ageing in the target regions. The anti-pattern object (AP) and the pattern object (P) are connected by a straight line that is referred to as the set axis. The set axis can represent the path of optimal development (advancement) with respect to population ageing. The set axis is divided into six equal parts by six isoquants, which connect points with the same degree of development. The further away a given isoquant is from the pattern object, the older the population of the target countries or regions that are marked within this particular isoquant.

Depending on the position of the pattern and anti-pattern object in the scaling space $\left[v_{i j}\right]_{(2 n+2) \times 2}$, the coordinate system needs to be rotated by an angle of $\varphi$, according to the formula (Bronsztejn et al. 2004, p. 206):

$$
\left[v_{i j}^{\prime}\right]_{(2 n+2) \times 2}=\left[v_{i j}\right]_{(2 n+2) \times 2} \times D,
$$

where: $\left[v_{i j}^{\prime}\right]_{(2 n+2) \times 2}-$ data matrix in a two-dimensional scaling space after rotating the coordinate system through an angle of $\varphi$,

$$
D=\left[\begin{array}{cc}
\cos \phi & -\sin \phi \\
\sin \phi & \cos \phi
\end{array}\right]-\text { rotation matrix. }
$$


In this case, the coordinate system was rotated by an angle of $\varphi=-0.7 \pi$. The rotation does not change the arrangement of the objects relative to each other. The set axis, which connects the pattern and anti-pattern, is placed along the main diagonal of Figure 2 in order to enhance the visualisation of the results.

In the next step, values of the aggregated measure were calculated (1). Table 1 shows the ranking of 80 target objects in terms of the degree of advancement of population ageing by the descending values of the aggregated measure (1).

Table 1 shows an ordering from the object with the lowest degree of advancement of population ageing to the object with the highest degree. The calculations were made using the clusterSim package (Walesiak and Dudek 2018a) of the R program (R Core Team 2018).

By comparing the results of multidimensional scaling (Figure 2) with the results of linear ordering of the 80 objects for 2005 and 2016 (Table 1), it is

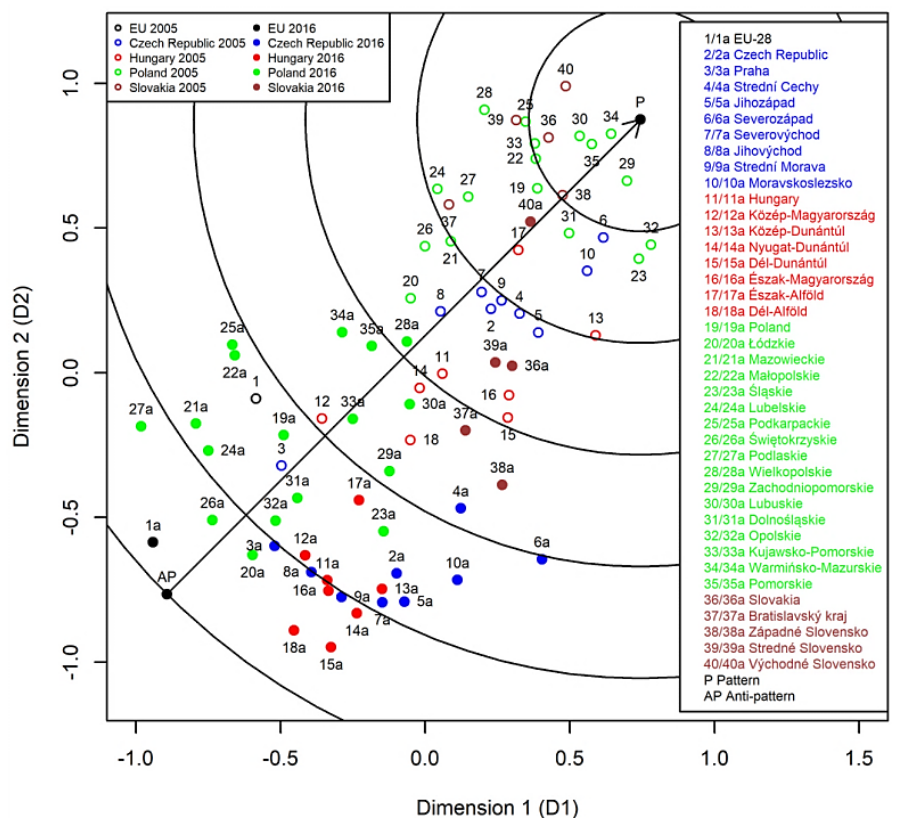

Fig. 2. Results of multidimensional scaling of 82 objects in terms of the degree of advancement of population ageing.

Source: own presentation. 
Table 1

Ranking of regions of the V4 countries, the EU-28 and the V4 countries by the degree of advancement of population ageing (in terms of measure $d_{i}$ ) for 2005 and 2016.

\begin{tabular}{|c|c|c|c|c|c|c|c|}
\hline $\begin{array}{l}\text { Object } \\
\text { ID }\end{array}$ & $\begin{array}{l}\text { Territorial } \\
\text { unit }\end{array}$ & $d_{i 2016}$ & $\begin{array}{c}\text { Rank } \\
\text { in } 2016\end{array}$ & $d_{i 2005}$ & $\begin{array}{c}\text { Rank } \\
\text { in } 2005\end{array}$ & $\Delta d_{i}$ & $\begin{array}{l}\text { Rank } \\
\text { change }\end{array}$ \\
\hline 40 & Východné Slovensko & 0.7761 & 1 & 0.8782 & 5 & -0.1021 & 4 \\
\hline 36 & Slovakia & 0.5860 & 2 & 0.8603 & 6 & -0.2744 & 4 \\
\hline 39 & Stredné Slovensko & 0.5780 & 3 & 0.8147 & 13 & -0.2367 & 10 \\
\hline 38 & Wielkopolskie & 0.5193 & 4 & 0.7671 & 17 & -0.2478 & 13 \\
\hline 35 & Pomorskie & 0.4760 & 5 & 0.9186 & 2 & -0.4426 & -3 \\
\hline 37 & Bratislavský kraj & 0.4678 & 6 & 0.6876 & 21 & -0.2198 & 15 \\
\hline 34 & Warmińsko-Mazurskie & 0.4536 & 7 & 0.9512 & 1 & -0.4976 & -6 \\
\hline 30 & Lubuskie & 0.4533 & 8 & 0.9061 & 4 & -0.4528 & -4 \\
\hline 38 & Západné Slovensko & 0.4175 & 9 & 0.8380 & 8 & -0.4205 & -1 \\
\hline 33 & Kujawsko-Pomorskie & 0.3808 & 10 & 0.8385 & 7 & -0.4577 & -3 \\
\hline 4 & Strední Cechy & 0.3612 & 11 & 0.6587 & 26 & -0.2975 & 15 \\
\hline 29 & Zachodniopomorskie & 0.3558 & 12 & 0.9063 & 3 & -0.5505 & -9 \\
\hline 6 & Severozápad & 0.3279 & 13 & 0.8154 & 11 & -0.4875 & -2 \\
\hline 25 & Podkarpackie & 0.3045 & 14 & 0.8287 & 10 & -0.5242 & -4 \\
\hline 22 & Małopolskie & 0.3003 & 15 & 0.8332 & 9 & -0.5329 & -6 \\
\hline 17 & Észak-Alföld & 0.2939 & 16 & 0.7336 & 19 & -0.4397 & 3 \\
\hline 19 & Poland & 0.2895 & 17 & 0.8149 & 12 & -0.5254 & -5 \\
\hline 23 & Śląskie & 0.2762 & 18 & 0.7923 & 16 & -0.5161 & -2 \\
\hline 10 & Moravskoslezsko & 0.2610 & 19 & 0.7606 & 18 & -0.4997 & -1 \\
\hline 31 & Dolnośląskie & 0.2382 & 20 & 0.7998 & 15 & -0.5616 & -5 \\
\hline 2 & Czech Republic & 0.2318 & 21 & 0.6403 & 29 & -0.4085 & 8 \\
\hline 13 & Közép-Dunántúl & 0.2006 & 22 & 0.6712 & 23 & -0.4706 & 1 \\
\hline 5 & Jihozápad & 0.1994 & 23 & 0.6477 & 28 & -0.4483 & 5 \\
\hline 21 & Mazowieckie & 0.1967 & 24 & 0.6638 & 24 & -0.4671 & 0 \\
\hline 32 & Opolskie & 0.1911 & 25 & 0.8123 & 14 & -0.6212 & -11 \\
\hline 24 & Lubelskie & 0.1881 & 26 & 0.6799 & 22 & -0.4917 & -4 \\
\hline 7 & Severovýchod & 0.1835 & 27 & 0.6504 & 27 & -0.4669 & 0 \\
\hline 12 & Közép-Magyarország & 0.1797 & 28 & 0.3484 & 38 & -0.1687 & 10 \\
\hline 11 & Hungary & 0.1691 & 29 & 0.5192 & 34 & -0.3500 & 5 \\
\hline 8 & Jihovýchod & 0.1655 & 30 & 0.5866 & 31 & -0.4212 & 1 \\
\hline 3 & Praha & 0.1618 & 31 & 0.2564 & 40 & -0.0946 & 9 \\
\hline 9 & Strední Morava & 0.1599 & 32 & 0.6599 & 25 & -0.5000 & -7 \\
\hline 16 & Észak-Magyarország & 0.1573 & 33 & 0.5443 & 33 & -0.3870 & 0 \\
\hline 14 & Nyugat-Dunántúl & 0.1511 & 34 & 0.4815 & 36 & -0.3305 & 2 \\
\hline 20 & Łódzkie & 0.1303 & 35 & 0.5658 & 32 & -0.4355 & -3 \\
\hline 26 & Świętokrzyskie & 0.1257 & 36 & 0.6272 & 30 & -0.5014 & -6 \\
\hline 27 & Podlaskie & 0.1257 & 37 & 0.7187 & 20 & -0.5929 & -17 \\
\hline 15 & Dél-Dunántúl & 0.0875 & 38 & 0.5135 & 35 & -0.4260 & -3 \\
\hline 18 & Dél-Alföld & 0.0793 & 39 & 0.4116 & 37 & -0.3322 & -2 \\
\hline 1 & EU-28 & 0.0374 & 40 & 0.2914 & 39 & -0.2539 & -1 \\
\hline & Parameters & \multicolumn{2}{|c|}{2016} & \multicolumn{2}{|c|}{2005} & \multicolumn{2}{|c|}{ change } \\
\hline & Mean & \multicolumn{2}{|c|}{0.2810} & \multicolumn{2}{|c|}{0.6923} & \multicolumn{2}{|c|}{-0.4114} \\
\hline & Standard deviation & \multicolumn{2}{|c|}{0.1594} & \multicolumn{2}{|c|}{0.1707} & \multicolumn{2}{|c|}{-0.0113} \\
\hline
\end{tabular}

Source: calculations made using the R software. 
possible to notice two kinds of changes (the two kinds of changes are not mutually exclusive and can co-occur):

1. A change in the degree of advancement of population ageing. Theoretically, one can distinguish three different states:

a) a rejuvenation of the population - indicated by a shift of objects towards the pattern object between the reference years (there are no regions representing this state in the results),

b) a stagnation in population ageing - indicated by the fact that objects remain in the same isoquants between the reference years (there are no regions representing this state in the results),

c) progressive population ageing - indicated by a shift of objects along the set axis towards the anti-pattern object between the reference years.

2. A shift of objects relative to the set axis (with objects moving closer to or further away from the axis or crossing the axis).

The first aspect to analyse in Figure 2 is the position of regions relative to the pattern (P) and anti-pattern (AP) object, which should be interpreted as follows: the closer a region is to the pattern object, the lower the degree of advancement of population ageing in that region. Conversely, an increasing proximity to the anti-pattern indicates an increasing degree of advancement of population ageing in a given region.

In general, it should be noted (see Figure 2 and Table 1) that in 2016 all regions have 'moved' towards the anti-pattern object (AP). This change is reflected by a decline in the average value of the aggregated measure $\left(\Delta \bar{d}_{i}=-0.4114\right)$, which means that populations in the analysed regions have grown older. The biggest decline in the aggregated measure $\left(\Delta d_{i}\right)$ can be observed for the following provinces of Poland: Opolskie (-0.6212), Podlaskie $(-0.5929)$, Dolnośląskie $(-0.5616)$, Zachodniopomorskie $(-0.5505)$. The smallest decline was recorded for the following regions: Praha $(-0.0946)$, Východné Slovensko (-0.1021) and Közép-Magyarország (-0.1687). It should be noted that in the reference years both Praha and KözépMagyarország were characterized by a very high degree of advancement of population ageing. In contrast to them, the population of Východné Slovensko was one of the youngest.

A comparison of values of the aggregated measure $d_{i}$ for 2005 and 2016 reveals that for 2005, in relative terms, the lowest degree of advancement of population ageing can be observed in the Polish provinces of Warmińsko-Mazurskie (34), Pomorskie (35), Zachodniopomorskie (29) and Lubuskie (30). For 2016 the situation is different: this time the Slovakian regions of Východné Slovensko (40a), Stredné Slovensko (39a) tops the 

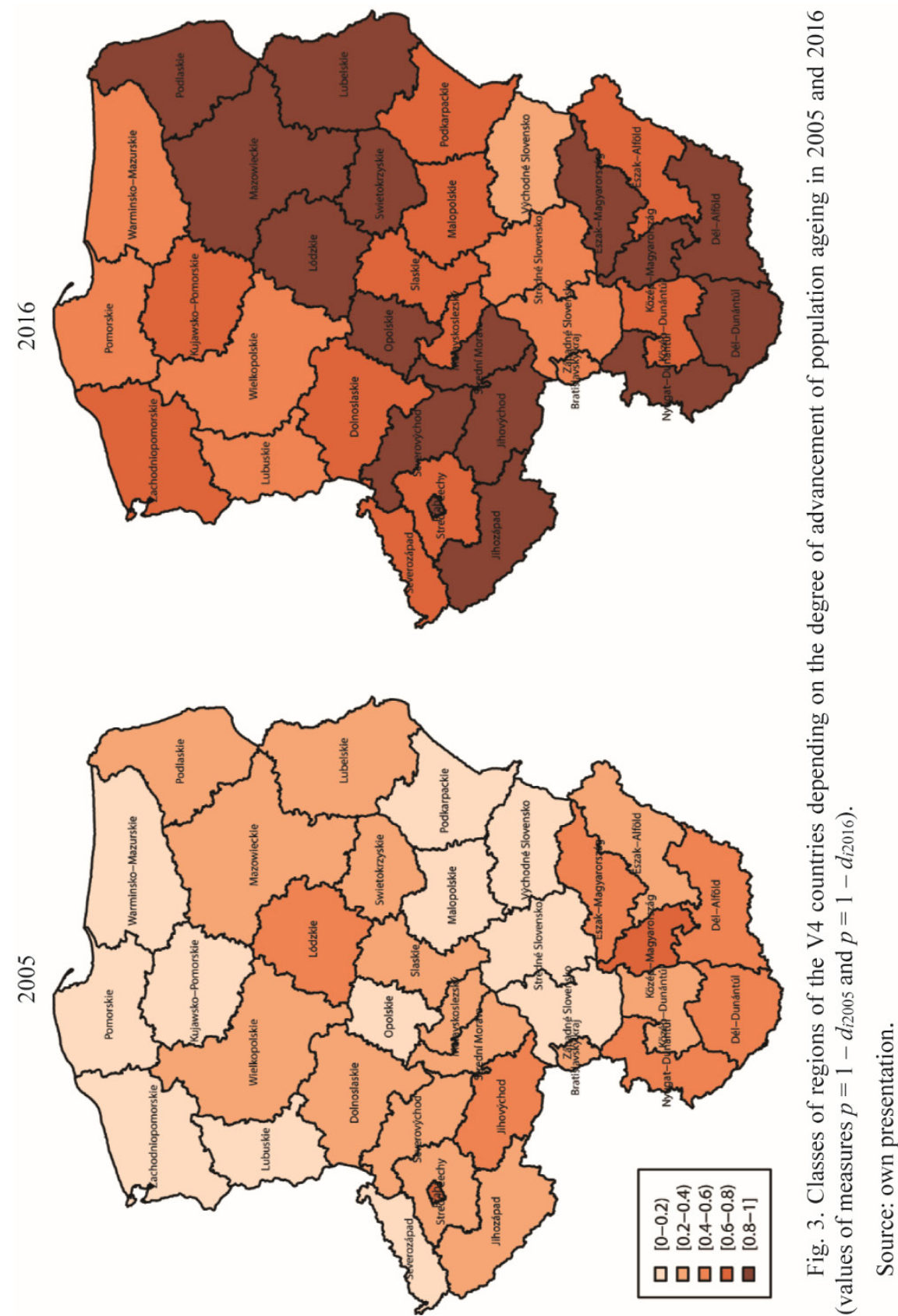
ranking, followed by the Polish provinces of Wielkopolskie (38a) and Pomorskie (35a).

The degree of advancement of population ageing in the regions of the V4 countries in 2005 and 2016 is illustrated in Figure 3.The class intervals are ordered from the lowest $[0-0.2]$ to the highest $[0.8-1]$ degree of advancement of population ageing.

To illustrate the shifts of regions between the reference years in the twodimensional chart (Figure 2), the authors calculated the distance of each object from the set axis (see Table 2 and Figure 4). A negative value in the column "Distance difference" in Table 2 represents a shift closer to the set axis (Figure $4 a$ ), while a positive value - a shift away from the axis (Figure $4 \mathrm{~b}$ ). The column "Sum of distances" refers to objects which crossed the set axis between the reference years (Figure 5). A higher value in this column represents a larger shift of the objects in the two-dimensional diagram.

The biggest shifts towards the set axis (see Figure 4a) can be observed for the regions of Wielkopolskie (28/28a), Opolskie (32/32a) and Východné Slovensko (40/40a). The smallest shifts towards the set axis can be seen for the regions of Łódzkie (20/20a) and Dolnośląskie (31/31a). The largest shift away from the axis between 2005 and 2016 can be observed for the regions of Severozápad (6/6a), Severovýchod (7/7a) and Západné Slovensko (38/38a). The smallest shift away from the axis between can be seen for the regions of Lubuskie (30/30a), Śląskie (23/23a), Pomorskie (35/35a) and Észak-Magyarország (16/16a).

When analysing the results, special attention was paid to objects that have 'crossed' the set axis between 2005 and 2016 (see Figure 5).

Two objects, representing the Slovakian (relatively young) regions of Bratislavský kraj (37/37a) and Stredné Slovensko (39/39a) have 'crossed' the set axis and are located at a considerable distance away from the set axis. A significant change in the configuration of variables is associated with a relatively small shift (see Table 1 , column $\Delta d_{i}$ ) along the set axis towards the anti-pattern (AP). The relatively old region of Praha (3/3a), has 'crossed' the set axis and its distance from the axis is the smallest. A minor change in the configuration of variables is associated with a relatively small shift along the set axis towards the anti-pattern (AP).

There is one more conclusion that can be drawn from analysing the twodimensional diagram (Figure 2). Namely, the same degree of advancement of population ageing characterizes objects (regions, EU-28) countries located at different points on the same isoquant of development (owing to different 
Table 2

Shifts in the two-dimensional diagram of objects representing regions of the V4 countries, the EU-28, and the four V4 countries indicating changes in the degree of advancement of population ageing between 2005 and 2016

\begin{tabular}{|c|c|c|c|c|c|}
\hline \multirow{2}{*}{$\begin{array}{c}\text { Object ID } \\
2005 / 2016\end{array}$} & \multirow[t]{2}{*}{ Territorial unit } & \multicolumn{2}{|c|}{$\begin{array}{c}\text { Euclidean distance from } \\
\text { the set axis }\end{array}$} & \multirow{2}{*}{$\begin{array}{l}\text { Distance } \\
\text { difference }\end{array}$} & \multirow{2}{*}{$\begin{array}{c}\text { Sum } \\
\text { of distances }\end{array}$} \\
\hline & & 2005 & 2016 & & \\
\hline $1 / 1 \mathrm{a}$ & EU-28 & 0.2592 & 0.1609 & -0.0983 & \\
\hline $2 / 2 \mathrm{a}$ & Czech Republic & 0.0969 & 0.5112 & 0.4143 & \\
\hline $3 / 3 a$ & Praha & 0.0330 & 0.1458 & 0.1128 & 0.1788 \\
\hline $4 / 4 a$ & Strední Cechy & 0.1783 & 0.5097 & 0.3314 & \\
\hline $5 / 5 a$ & Jihozápad & 0.2698 & 0.5996 & 0.3298 & \\
\hline $6 / 6 a$ & Severozápad & 0.1978 & 0.8333 & 0.6355 & \\
\hline $7 / 7 \mathrm{a}$ & Severovýchod & 0.0331 & 0.5474 & 0.5143 & \\
\hline $8 / 8 a$ & Jihovýchod & 0.0200 & 0.2998 & 0.2798 & 0.3198 \\
\hline $9 / 9 a$ & Strední Morava & 0.1023 & 0.4348 & 0.3325 & \\
\hline $10 / 10 \mathrm{a}$ & Moravskoslezsko & 0.2399 & 0.6762 & 0.4364 & \\
\hline $11 / 11 \mathrm{a}$ & Hungary & 0.1361 & 0.3587 & 0.2227 & \\
\hline $12 / 12 \mathrm{a}$ & Közép-Magyarország & 0.0490 & 0.2433 & 0.1943 & 0.2923 \\
\hline $13 / 13 a$ & Közép-Dunántúl & 0.4176 & 0.5136 & 0.0960 & \\
\hline $14 / 14 a$ & Nyugat-Dunántúl & 0.1149 & 0.5112 & 0.3964 & \\
\hline $15 / 15 \mathrm{a}$ & Dél-Dunántúl & 0.4032 & 0.5310 & 0.1278 & \\
\hline $16 / 16 a$ & Észak-Magyarország & 0.3514 & 0.3872 & 0.0357 & \\
\hline $17 / 17 \mathrm{a}$ & Észak-Alföld & 0.0200 & 0.2411 & 0.2212 & \\
\hline $18 / 18 \mathrm{a}$ & Dél-Alföld & 0.2195 & 0.3994 & 0.1799 & \\
\hline $19 / 19 a$ & Poland & 0.0841 & 0.1023 & 0.0183 & \\
\hline $20 / 20 a$ & Łódzkie & 0.1256 & 0.1138 & -0.0118 & 0.2394 \\
\hline $21 / 21 \mathrm{a}$ & Mazowieckie & 0.1668 & 0.3449 & 0.1781 & \\
\hline $22 / 22 a$ & Małopolskie & 0.1600 & 0.4167 & 0.2566 & \\
\hline $23 / 23 a$ & Śląskie & 0.3364 & 0.3764 & 0.0400 & \\
\hline $24 / 24 a$ & Lubelskie & 0.3269 & 0.2492 & -0.0777 & \\
\hline $25 / 25 a$ & Podkarpackie & 0.2752 & 0.4493 & 0.1741 & \\
\hline $26 / 26 a$ & Świętokrzyskie & 0.2175 & 0.0697 & -0.1477 & \\
\hline $27 / 27 \mathrm{a}$ & Podlaskie & 0.2325 & 0.4732 & 0.2407 & \\
\hline $28 / 28 \mathrm{a}$ & Wielkopolskie & 0.4048 & 0.0294 & -0.3754 & \\
\hline $29 / 29 a$ & Zachodniopomorskie & 0.1171 & 0.2444 & 0.1273 & \\
\hline $30 / 30 a$ & Lubuskie & 0.1078 & 0.1304 & 0.0226 & 0.2383 \\
\hline $31 / 31 \mathrm{a}$ & Dolnośląskie & 0.1037 & 0.0842 & -0.0194 & \\
\hline $32 / 32 a$ & Opolskie & 0.3323 & 0.0863 & -0.2460 & \\
\hline $33 / 33 a$ & Kujawsko-Pomorskie & 0.1998 & 0.0271 & -0.1728 & 0.2269 \\
\hline $34 / 34 a$ & Warmińsko-Mazurskie & 0.0368 & 0.2105 & 0.1736 & \\
\hline $35 / 35 a$ & Pomorskie & 0.0586 & 0.1040 & 0.0454 & \\
\hline $36 / 36 a$ & Slovakia & 0.1805 & 0.2876 & 0.1072 & 0.4681 \\
\hline $37 / 37 \mathrm{a}$ & Bratislavský kraj & 0.2602 & 0.3312 & 0.0710 & 0.5915 \\
\hline $38 / 38 \mathrm{a}$ & Západné Slovensko & 0.0053 & 0.5534 & 0.5480 & 0.5587 \\
\hline $39 / 39 a$ & Stredné Slovensko & 0.3018 & 0.2381 & -0.0636 & 0.5399 \\
\hline $40 / 40 \mathrm{a}$ & Východné Slovensko & 0.2634 & 0.0198 & -0.2435 & \\
\hline
\end{tabular}

Source: calculations made using the R software.

${ }^{2}$ In the case of an object crossing the set axis. 
a

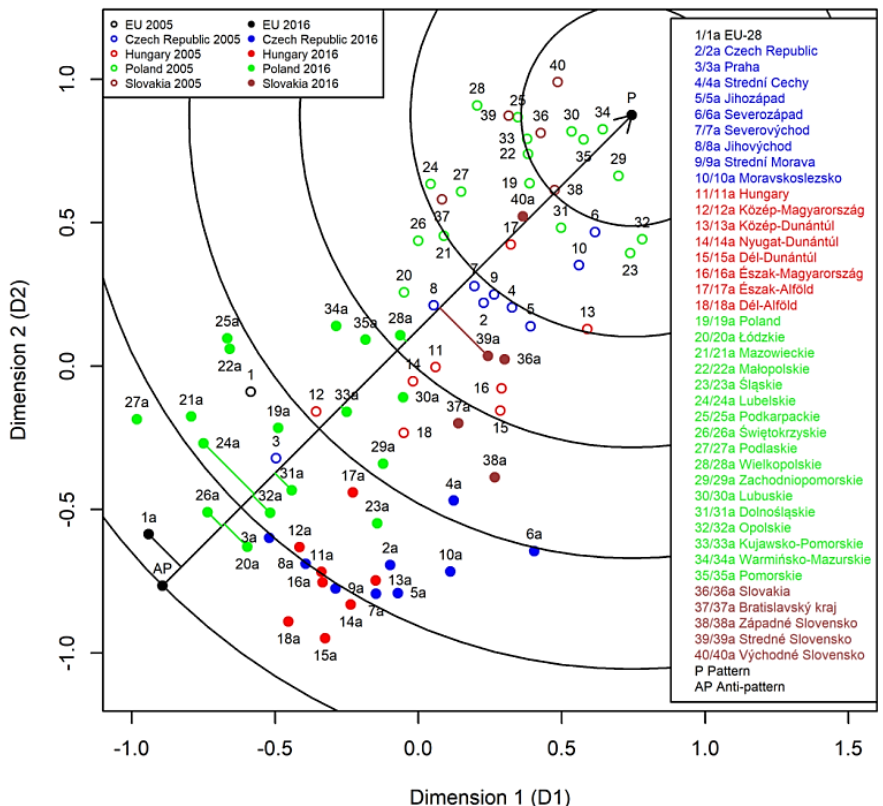

$\mathrm{b}$

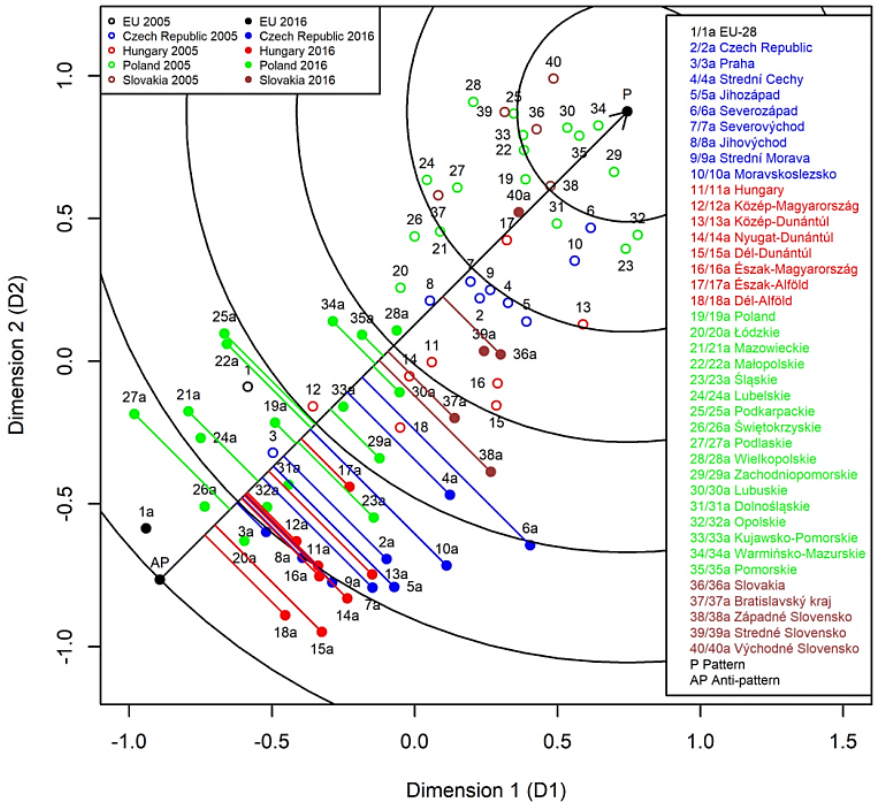

Fig. 4. Distances of objects from the set axis in the two-dimensional diagram in 2016 ( $a$ - shift towards the set axis, b - shift away from the set axis).

Source: own presentation. 


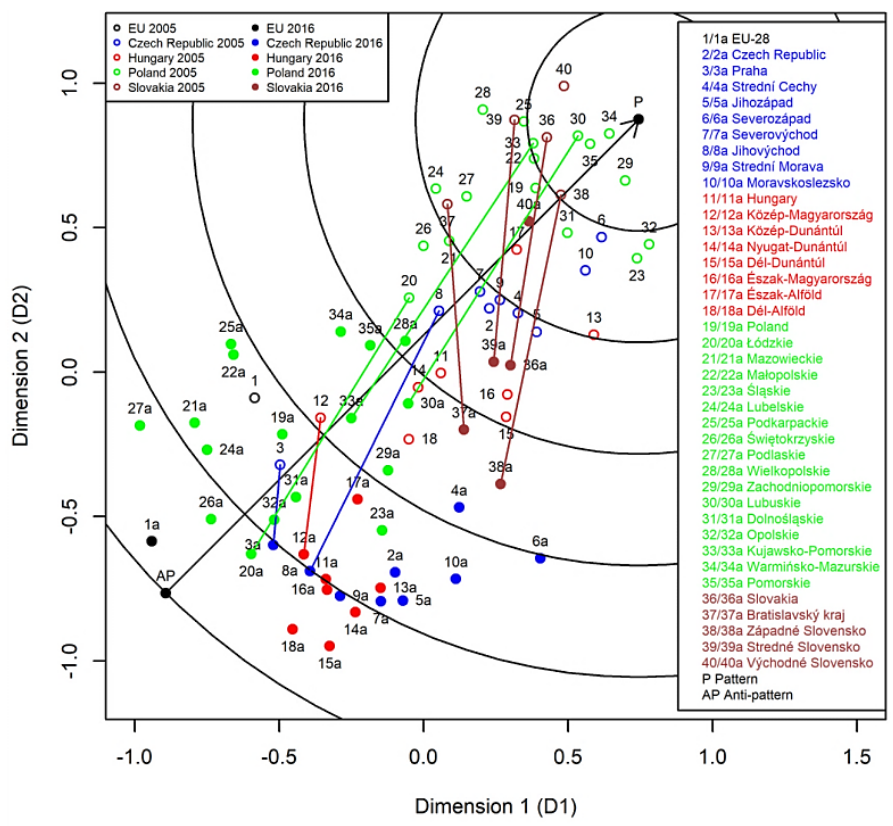

Fig. 5. Shifts of objects between 2005 and 2016 (objects which 'crossed' the set axis of the two-dimensional diagram).

Source: own presentation.

configurations of the target variables). For 2005, this observation is true for the regions of Lubelskie (24), Strední Morava (9) and Közép-Dunántúl (13), and for 2016, for example for the regions of Jihozápad (5a), Mazowieckie (21a) and Opolskie (32a).

The authors selected two isoquants -the first and fifth (counting from the pattern) - to identify regions characterized by a similar configuration of the variables and examine interrelationships between them for 2005 (isoquant 1, Table 3A) and for 2016 (isoquant 5, Table 3B).

For 2005, the group objects (regions) are located on the first isoquant, which represents the youngest population (regions located relatively close to the pattern object $\mathrm{P}$ ):

- to the left of the set axis AP-P: the Polish regions of Podkarpackie (25) and Małopolskie (22),

- on the set axis AP-P: the Slovakian region of Západné Slovensko (38),

- to the right of the set axis AP-P: the Czech region of Severozápad (6), the Polish region of Opolskie (32). 
Table 3

Characteristics of selected regions located within the same isoquant

\begin{tabular}{|c|c|c|c|c|c|c|}
\hline \multicolumn{7}{|c|}{ A. Characteristics of selected regions located within isoquant 1} \\
\hline \multirow{2}{*}{ Region ID } & \multirow{2}{*}{ Region name } & \multicolumn{5}{|c|}{ Variables } \\
\hline & & $\mathrm{x} 1$ & $\mathrm{x} 2$ & $\mathrm{x} 3$ & $\mathrm{x} 4$ & $\mathrm{x} 5$ \\
\hline 25 & Podkarpackie & 34.2 & 16.41 & 14.79 & 87.47 & 18.6 \\
\hline 22 & Małopolskie & 35.0 & 17.13 & 14.75 & 96.01 & 19.2 \\
\hline 38 & Západné Slovensko & 36.7 & 17.13 & 14.62 & 109.55 & 17.2 \\
\hline 6 & Severozápad & 37.7 & 17.98 & 13.77 & 114.00 & 17.4 \\
\hline 32 & Opolskie & 37.2 & 17.50 & 12.51 & 111.44 & 18.7 \\
\hline \multicolumn{2}{|c|}{ Object located at the intersection of the isoquant and the set axis } & 35.6 & 17.65 & 14.66 & 103.72 & 18.7 \\
\hline \multicolumn{7}{|c|}{ B. Characteristics of selected regions located within isoquant 5} \\
\hline \multirow{2}{*}{ Region ID } & \multirow{2}{*}{ Region name } & \multicolumn{5}{|c|}{ Variables } \\
\hline & & $\mathrm{x} 1$ & $\mathrm{x} 2$ & $\mathrm{x} 3$ & $\mathrm{x} 4$ & $\mathrm{x} 5$ \\
\hline $21 \mathrm{a}$ & Mazowieckie & 39.6 & 23.33 & 19.57 & 148.08 & 24.0 \\
\hline $24 a$ & Lubelskie & 39.9 & 23.45 & 19.27 & 159.13 & 24.0 \\
\hline $32 \mathrm{a}$ & Opolskie & 41.5 & 24.17 & 17.66 & 178.28 & 24.4 \\
\hline $12 \mathrm{a}$ & Közép-Magyarország & 41.1 & 25.30 & 17.09 & 171.33 & 27.2 \\
\hline $7 \mathrm{a}$ & Severovýchod & 41.7 & 25.90 & 15.98 & 168.05 & 28.7 \\
\hline \multicolumn{2}{|c|}{ Object located at the intersection of the isoquant and the set axis } & 40.9 & 23.88 & 18.96 & 165.01 & 25.5 \\
\hline
\end{tabular}

Source: own calculations.

It can be noticed that, compared to the object located at the intersection of the isoquant and the axis, the regions located to the left of the axis are characterised by lower median age $(\mathrm{x} 1)$, lower percentage of the population aged 60 and over (x2) and lower aging index (x4). The opposite situation occurs in the case of double ageing index (x3): higher values are associated with the regions located to the left of the axis. There is no such pattern in the case of the old-age dependency ratio (x5). It can therefore be concluded that it is the value of the double ageing index that significantly differentiates regions with a similar degree of advancement of population ageing.

For 2016, the group of objects (regions) located on or in the vicinity of the fifth isoquant, which represents the population with the oldest age structure (regions located relatively close to the anti-pattern object) include:

- to the left of the axis AP-P: the Polish regions of Mazowieckie (21a) and Lubelskie (24a),

- on the axis AP-P: the Polish region of Opolskie (32a),

- to the right of the axis AP-P: the Hungarian region of KözépMagyarország (12a), and the Czech region of Severovýchod (7a).

Like in the case of 2005, compared to the object located at the intersection of the isoquant and the axis AP-P, the regions located to the left 
of the set axis are characterized by lower median age (x1), lower percentage of the population aged 60 and over (x2), lower ageing index (x4), and lower old-age dependency ratio (x5); it is the opposite in the case of the double ageing index $(\mathrm{x} 3)$ : higher values are associated with the regions located to the left of the axis. Once again, the value of the double ageing index significantly differentiates regions with a similar degree of advancement of population ageing. This situation can be explained by the differences associated with demographic structures. In all the countries and regions analysed in the study, the percentage of people aged $65+$ is increasing. This dynamic growth is becoming even more dynamic, when consecutive groups of peers entering the post-productive age are more numerous (these are groups of people born during the post-war demographic boom). If the size of age groups entering the post-productive age, i.e. those crossing the 'old age' threshold, is considerably larger than the size of age groups crossing the 'oldest-old age' threshold ( 80 years and over), one can observe a reversal of the growing trend of double ageing. This explanation does not rule out other factors that affect the value of the double ageing index (x3), and which are related to the pace at which life expectancy is increasing, the development of medical services and health care, a healthier lifestyle, an improvement in the standard of living, etc.

Analysing the regions located on the same isoquant, one can see that their proximity to the set axis corresponds to the situation when all measures of population ageing are similar to the object located at the intersection of the isoquant and the axis. When their values are close to the average ones (which represent the object whose coordinates are located at the intersection of the isoquant and the axis), variables for such an object are not very different (compare Západné Slovensko (38) - Figure 6a with Opolskie province (32a) - Figure 6b). As the object's distance from the set axis increases, the measures of population ageing either become higher or smaller than the 'average' ones (which represent the object whose coordinates are located at the intersection of the isoquant and the axis) and are much more differentiated. The further away the object (region) is from the set axis, the more differentiated the diagnostic variables are. This situation is exemplified by the provinces of Podkarpackie (25) and Opolskie (32) in Figure 6a and the provinces of Mazowieckie (21a), Lubelskie (24a) and the Czech region of Severovýchod (7a) in Figure 6b.

To obtain a general assessment of the changes and degree of advancement of population ageing in regions of the V4 countries for 2005 and 2016, the authors used Theil's decomposition. After applying the appropriate $\mathrm{R}$ function, the following results were obtained, which are presented in Table 4. 


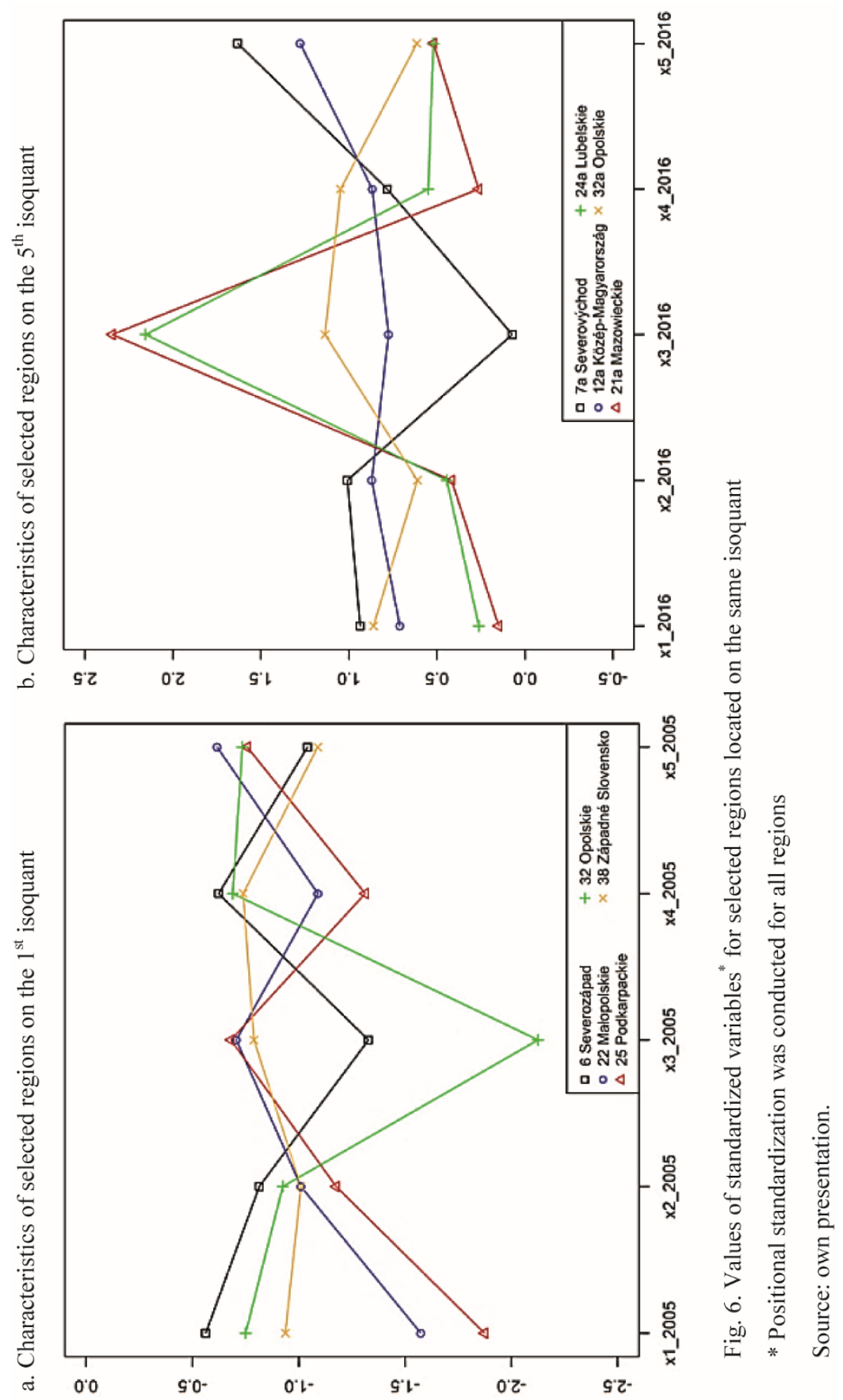


Table 4

Results of Theil's decomposition (formulas (2)-(6))

\begin{tabular}{|c|c|c|c|c|c|c|c|c|c|c|c|c|}
\hline \multirow[t]{2}{*}{ Measure } & \multicolumn{2}{|c|}{ Overall ${ }^{*}$} & \multicolumn{2}{|c|}{$\begin{array}{l}\text { Czech Republic } \\
\text { (8 regions) }\end{array}$} & \multicolumn{2}{|c|}{$\begin{array}{l}\text { Hungary } \\
\text { (7 regions) }\end{array}$} & \multicolumn{2}{|c|}{$\begin{array}{c}\text { Poland } \\
\text { (16 regions) }\end{array}$} & \multicolumn{2}{|c|}{$\begin{array}{l}\text { Slovakia } \\
\text { (4 regions) }\end{array}$} & \multicolumn{2}{|c|}{ Others $^{* *}$} \\
\hline & $q$ & $t$ & $q$ & $t$ & $q$ & $t$ & $Q$ & $t$ & $q$ & $t$ & $q$ & $t$ \\
\hline $\bar{d}$ & 0.6923 & 0.2810 & 0.6295 & 0.2275 & 0.5292 & 0.1642 & 0.7881 & 0.2947 & 0.8046 & 0.5599 & 0.6252 & 0.2628 \\
\hline$S$ & 0.1707 & 0.1594 & 0.1563 & 0.0746 & 0.1260 & 0.0673 & 0.1079 & 0.1285 & 0.0713 & 0.1377 & 0.2070 & 0.1820 \\
\hline$r$ & \multicolumn{2}{|c|}{0.7018} & \multicolumn{2}{|c|}{0.5430} & \multicolumn{2}{|c|}{0.6836} & \multicolumn{2}{|c|}{0.7740} & \multicolumn{2}{|c|}{0.5633} & \multicolumn{2}{|c|}{0.8799} \\
\hline$W$ & \multicolumn{2}{|c|}{0.4308} & \multicolumn{2}{|c|}{0.4229} & \multicolumn{2}{|c|}{0.3768} & \multicolumn{2}{|c|}{0.5001} & \multicolumn{2}{|c|}{0.2700} & \multicolumn{2}{|c|}{0.3755} \\
\hline$W^{2}$ & \multicolumn{2}{|c|}{0.1856} & \multicolumn{2}{|c|}{0.1789} & \multicolumn{2}{|c|}{0.1420} & \multicolumn{2}{|c|}{0.2501} & \multicolumn{2}{|c|}{0.0729} & \multicolumn{2}{|c|}{0.1410} \\
\hline$W_{1}^{2}$ & \multicolumn{2}{|c|}{$\begin{array}{c}0.1692 \\
(91.19 \%) \\
\end{array}$} & \multicolumn{2}{|c|}{$\begin{array}{c}0.1616 \\
(90.28 \%)\end{array}$} & \multicolumn{2}{|c|}{$\begin{array}{c}0.1332 \\
(93.74 \%)\end{array}$} & \multicolumn{2}{|c|}{$\begin{array}{c}0.2434 \\
(97.32 \%)\end{array}$} & \multicolumn{2}{|c|}{$\begin{array}{c}0.0599 \\
(82.17 \%)\end{array}$} & \multicolumn{2}{|c|}{$\begin{array}{c}0.1314 \\
(93.14 \%)\end{array}$} \\
\hline$W_{2}^{2}$ & \multicolumn{2}{|c|}{$\begin{array}{l}0.00013 \\
(0.07 \%)\end{array}$} & \multicolumn{2}{|c|}{$\begin{array}{c}0.0067 \\
(3.74 \%)\end{array}$} & \multicolumn{2}{|c|}{$\begin{array}{c}0.0035 \\
(2.46 \%)\end{array}$} & \multicolumn{2}{|c|}{$\begin{array}{c}0.0004 \\
(0.16 \%)\end{array}$} & \multicolumn{2}{|c|}{$\begin{array}{c}0.0044 \\
(6.03 \%)\end{array}$} & \multicolumn{2}{|c|}{$\begin{array}{l}0.00062 \\
(0.44 \%)\end{array}$} \\
\hline$W_{3}^{2}$ & \multicolumn{2}{|c|}{$\begin{array}{c}0.0162 \\
(8.74 \%)\end{array}$} & $\begin{array}{r}0.0 \\
(5.9\end{array}$ & $\begin{array}{l}107 \\
8 \%)\end{array}$ & $\begin{array}{r}0.0 \\
(3.8\end{array}$ & $\begin{array}{l}054 \\
0 \%)\end{array}$ & $\begin{array}{l}0.0 \\
(2.5\end{array}$ & $\begin{array}{l}063 \\
2 \%)\end{array}$ & $\begin{array}{r}0.0 \\
(11.8\end{array}$ & $\begin{array}{l}086 \\
30 \%)\end{array}$ & $\begin{array}{l}0.00 \\
(6.4\end{array}$ & $\begin{array}{l}905 \\
2 \%)\end{array}$ \\
\hline
\end{tabular}

* weighted arithmetic mean, ${ }^{* *}$ EU-28, the Czech Republic, Hungary, Poland, Slovakia, $q=2005, t=2016$

Source: calculations made using the R software.

The average deviation of aggregated measures $\left(d_{i}\right)$ for 2005 and 2016 (measure $W$ ) is equal to 0.4308 . This is mainly due to the decline in the mean value of the aggregated measure $d_{i}\left(W_{1}^{2}=0.1692\right)$, which means a considerable acceleration of population ageing in the regions (a fall in the mean value of the aggregated measure by 0.4114). Between 2005 and 2016 there is a slight fall in values of the aggregated measure $d_{i}$, which can be interpreted as a sign of a smaller disproportion between the regions in terms of population ageing $\left(W_{2}^{2}=0.00013\right.$ for $S_{q}=0.1707$ and $\left.S_{t}=0.1594\right)$. The relatively high consistency in the direction of changes in the value of the aggregated measure $d_{i}$ for the two reference years is observed $\left(W_{3}^{2}=0.0162\right.$ for $\left.r=0.7018\right)$.

The Polish provinces, which are the largest group of regions (16) belonging to one country, have the biggest impact on values of overall measure $W(0.5001)$. In contrast, the influence of the four regions of Slovakia, which form the smallest group, is the weakest (0.2700). The results for the Czech Republic are closest to the average for all four countries (0.4229). The changes in measure $W$, in each of the V4 countries can be attributed mainly to a decline in the mean values of the aggregated measure $\left(W_{1}^{2}\right)$. The contribution of this component in Theil's decomposition ranges 
from $82.17 \%$ (Slovakia) to $97.32 \%$ (Poland). In Slovakia the contribution of values of $W_{2}^{2}(6.03 \%)$ and $W_{3}^{2}(11.8 \%)$ in Theil's decomposition are relatively high. The disproportion between regions, in terms of population ageing, has increased in Slovakia, slightly increased in Poland, and decreased in the Czech Republic and Hungary. The direction of changes in values of aggregated measure between the two reference years is largely consistent (the smallest values, in this parameter, was observed in the Czech Republic and Slovakia).

\section{CONCLUSIONS}

Any comparative analysis is typically based on relative measures. The literature describes a large number of relative measures of population ageing, which is why any particular choice will always be debatable. Moreover, attempts to conduct such an analysis at a regional level would further be complicated by changes in the administrative division and limited data accessibility. However, empirical research indicates that regardless of what measures are selected, results of analyses are similar (Murphy 2017). This does not change the fact that many measures, particularly those relating to the percentage of the old age population, have their drawbacks (Murphy 2017). Some of the key problems in this respect include the determination of the threshold of old age, failure to account for structural changes in the age interval above the old age threshold, and a one-sided view of population ageing, which focuses on the top of the population pyramid.

The study investigates the variation in population ageing in V4 countries (the Czech Republic, Poland, Slovakia and Hungary) across their NUTS2 regions in 2016 compared to 2005 using traditional measures of population ageing. Given the growing demand for information about small territorial units, the analysis was conducted at the level of regions.

The measurement of ageing is complex and requires a multivariate approach. To solve the empirical problem the authors applied in the research methodology multidimensional scaling combined with linear ordering and Theil's decomposition.

The most interesting findings of the study are the changes in the degree of advancement of population ageing between 2005 and 2016. None of the regions in the V4 countries show evidence of a rejuvenation of the population. On the contrary, all the regions exhibit symptoms of progressive population ageing, reflected by a shift towards the anti-pattern. 
In the reference period the process of population ageing in the V4 countries and their regions accelerated considerably. The smallest changes can be observed in Slovakia and its regions. The greatest changes in ageing occurred in the Polish provinces.

The study also revealed a slight decline in the degree of variation between all regions in the V4 countries in terms of population ageing. Taking into account the regions of each country of V4 separately, a disproportion between regions has increased in Slovakia, slightly increased in Poland, and decreased in the Czech Republic and Hungary.

The authors are well aware of the limitations of the study that are due to the selected set of variables and the methodology used. The benefit associated with the particular set of variables used is that they reflect changes in population ageing both at the bottom and at the top of the population pyramid. By applying multidimensional scaling, some information is lost but the results can be presented graphically in a two-dimensional space, which facilitates their interpretation.

The calculations and graphics were based on own scripts prepared in $\mathrm{R}$ environment.

\section{REFERENCES}

Beard, J. R., Biggs, S., Bloom, D. E., Fried, L. P., Hogan, P., Kalache, A., Olshansky, S. J. (eds.), Global Population Ageing: Peril or Promise. World Economic Forum, Geneva 2012. URL http://www3.weforum.org/docs/WEF_GAC_GlobalPopulationAgeing_ Report_2012.pdf. Accessed 10 November 2017.

Bongaarts, J., Population aging and the rising cost of public pensions, "Population and Development Review", vol. 30, issue 1, pp. 1-23, 2004. URL https://doi.org/10.1111/ j.1728-4457.2004.00001.x.

Borg, I., Groenen, P. J. F., Modern multidimensional scaling. Theory and applications, 2nd Edition. Springer Science+Business Media, New York 2005.

Börsch-Supan, A., Labor market effects of population aging, "Labour", vol. 17, issue s1, pp. 5-44, 2003. URL https://doi.org/10.1111/1467-9914.17.specialissue.2.

Bronsztejn, I. N., Siemiendiajew, K. A., Musiol, G., Mühlig, H., Nowoczesne kompendium matematyki [A modern compendium of mathematics]. PWN, Warsaw 2004.

Bussolo, M., Koettl, J., Sinnott, E., Golden Ageing. Prospects for Healthy, Active, and Prosperous Aging in Europe and Central Asia. The World Bank, Washington DC 2015. URL https://openknowledge.worldbank.org/handle/10986/22018. Accessed 10 November 2017.

Dehnel, G., Gołata, E., Obrębalski, M., Walesiak, M., Ocena zmian w procesie starzenia się ludności w regionach krajów Grupy Wyszehradzkiej z zastosowaniem wybranych metod statystycznej analizy wielowymiarowej [Assessment of changes in the aging process of 
population in the regions of Visegrad group with the application of chosen methods of multidimensional statistical analysis], "Prace Naukowe Uniwersytetu Ekonomicznego we Wrocławiu", no. 507, pp. 39-52, 2018. URL http://dx.doi.org/10.15611/pn.2018.507.04.

Everitt, B. S., Landau, S., Leese, M., Stahl, D., Cluster Analysis. John Wiley \& Sons, Chichester 2011.

Goldstein, J. R., Sobotka, T., Jasilioniene, A., The end of "lowest-low" fertility?, "Population and Development Review", vol. 35, issue 4, pp. 663-699, 2009. URL https://doi.org/ 10.1111/j.1728-4457.2009.00304.x.

Hellwig, Z., Wielowymiarowa analiza porównawcza $i$ jej zastosowanie $w$ badaniach wielocechowych obiektów gospodarczych [Multivariate Comparative Analysis and its Application in Multifeature Economic Objects] [in:] Welfe, W. (ed.), Metody i modele ekonomiczno-matematyczne $w$ doskonaleniu zarzadzania gospodarka socjalistyczna [Economic and Mathematical Methods and Models in the Improvement of Socialist Economy Management], pp. 46-68. PWE, Warsaw 1981.

Jajuga, K., Walesiak, M., Bąk, A., On the General Distance Measure [in:] Schwaiger, M., Opitz, O., (eds.), Exploratory Data Analysis in Empirical Research, pp. 104-109. Berlin, Heidelberg, Springer-Verlag 2003. URL https://dx.doi.org/10.1007/978-3-642-55721-7_12.

Káčerová, M., Ondačková, J., The process of population ageing in countries of the Visegrad Group (V4), "Erdkunde", vol. 69, issue 1, pp. 49-68, 2015. URL https://doi.org/ 10.3112/erdkunde.2015.01.04.

Káčerová, M., Ondačková, J., Mládek, J., Time-space differences of population ageing in Europe, "Hungarian Geographical Bulletin", vol. 63, no. 2, pp. 177-199, 2014. URL https://doi.org/10.15201/hungeobull.63.2.4.

Lee, R., Edwards, R., The Fiscal Effects of Population Aging in the U.S.: Assessing the Uncertainties [in:] Poterba, J. M. (ed.), Tax Policy and the Economy, vol. 16, pp. 141-180. MIT Press, Cambridge 2002. URL http://www.nber.org/chapters/c10865.pdf.

Lee, R., Mason, A., Fertility, human capital, and economic growth over the demographic transition, "European Journal of Population", vol. 26, issue 2, pp. 159-182, 2010. URL https://dx.doi.org/10.1007/s10680-009-9186-x.

Lutz, W., Skirbekk, V., Testa, M. R., The low-fertility trap hypothesis: Forces that may lead to further postponement and fewer births in Europe [in:] Philipov, D., Liefbroer, A. C., Billari, F. C. (eds.), Vienna Yearbook of Population Research 2006, pp. 167-192. Austrian Academy of Sciences Press, Wien 2006. URL https://dx.doi.org/10.1553/ populationyearbook2006s167.

Mair, P., De Leeuw, J., Borg, I., Groenen, P. J. F., smacof: Multidimensional Scaling. R package version 1.10-8, 2018. URL http://CRAN.R-project.org/package=smacof.

Metz, D. H., Mobility of older people and their quality of life, "Transport Policy", vol. 7, issue 2, pp. 149-152, 2000. URL https://doi.org/10.1016/S0967-070X(00)00004-4.

Miller, T., Increasing longevity and medicare expenditures, "Demography", vol. 38, issue 2, pp. 215-226, 2001. URL https://dx.doi.org/10.1353/dem.2001.0018.

Murphy, M., Demographic Determinants of Population Aging in Europe since 1850, "Population and Development Review", vol. 43, issue 2, pp. 257-283, 2017. URL https://doi.org/10.1111/padr.12073. 
Polasek, W., Forecast Evaluations for Multiple Time Series: a Generalized Theil Decomposition, Working Paper series 23_13, Rimini Centre for Economic Analysis, Rimini 2013. URL https://ideas.repec.org/p/rim/rimwps/23_13.html.

Preston, S. H., Himes, C., Eggers, M., Demographic Conditions Responsible for Population Aging, "Demography", vol. 26, issue 4, pp. 691-704, 1989. URL https://link.springer. com/article/10.2307/2061266.

$\mathrm{R}$ Core Team, R: A Language and Environment for Statistical Computing. R Foundation for Statistical Computing, Vienna 2018. URL https://www.R-project.org.

Rosset, E., Ludzie starzy. Studium demograficzne [Old people. Demographic study]. Państwowe Wydawnictwo Ekonomiczne, Warsaw 1967.

Sanderson, W. C., Scherbov, S., Remeasuring Ageing, "Science", vol. 329, issue 5997, 10 September, pp. 1287-1288, 2010. URL https://doi.org/10.1126/science.1193647.

Sauvy, A., La nature sociale. Introduction a la psychologie politique. Armand Colin, Paris 1957.

The 2015 Ageing Report, European Commission, Brussels 2015. URL http://www.aal-europe. eu/wp-content/uploads/2015/08/Ageing-Report-2015.pdf. Accessed 10 November 2017.

Theil, H., Economic Forecasts and Policy. North Holland, Amsterdam 1961.

Walesiak, M., Visualization of Linear Ordering Results for Metric Data with the Application of Multidimensional Scaling, "Ekonometria", 2 (52), pp. 9-21, 2016. URL http://dx.doi. org/10.15611/ekt.2016.2.01.

Walesiak, M., Dudek, A., clusterSim: Searching for Optimal Clustering Procedure for a Data Set. R package version $0.47-3,2018$ a. URL https:/CRAN.R-project.org/package $=$ clusterSim.

Walesiak, M., Dudek, A., mdsOpt: Searching for Optimal MDS Procedure for Metric and Interval-Valued Data. R package version 0.3-3, 2018b. URL https://CRAN.R-project.org/ package $=$ mdsOpt.

World Population Ageing. United Nations, New York 2015. URL http://www.un.org/en/ development/desa/population/publications/pdf/ageing/WPA2015_Report.pdf. Accessed 10 November 2017.

World Population Prospects. The 2017 Revision. Key Findings and Advance Tables. United Nations, New York 2017. URL https://reliefweb.int/report/world/world-populationprospects-2017-revision-key-findings-and-advance-tables. Accessed 8 April 2020.

Received: April 2018, revised: January 2019 